\title{
SOCIAL COMMERCE SOUVENIR UKM UNI-QUE DESIGN
}

\author{
Tri Listyorini \\ Fakultas Teknik, Program Studi Teknik Informatika \\ Universitas Muria Kudus \\ Email: trilistyorini@umk.ac.id \\ Rizkysari Meimaharani \\ Fakultas Teknik, Program Studi Teknik Informatika \\ Universitas Muria Kudus \\ Email: rizky.sari@umk.ac.id
}

\begin{abstract}
ABSTRAK
Social Commerce merupakan salah satu ilmu dalam teknologi informasi. Manfaat dari social commerce dapat dirasakan oleh para UKM, karena dengan adanya social commerce proses penjualan dari UKM dapat terbantu. Salah satunya adalah UKM Uni-que Design yang bergerak dalam produksi aksesoris. Untuk meningkatkan promosi dari UKM tersebut memanfaatkan social commerce. Menggunakan metode pengembangan sistem yang terdiri dari analisa, perancangan, pembuatan dan implementasi. Tujuan dari penelitian ini adalah pendampingan penerapan social commerce untuk UKM Uni-que Design dalam memperluas pemasaran dari produknya. Hasil dari penelitian ini adalah sebuah aplikasi dengan sosial media dalam pemasaran produk UKM.
\end{abstract}

Kata kunci: social commerce; UKM; teknologi informasi.

\section{ABSTRACT}

Social Commerce is one of the sciences in information technology. The benefits of social commerce can be felt by UKM, because with the existence of social commerce the sales process of SMEs can be helped. One of them is Uni-que Design UKM engaged in the production of accessories. To improve the promotion of these UKM, use social commerce. Using system development methods consisting of analysis, design, manufacture and implementation. The purpose of this research is to assist the implementation of social commerce for UKM Uni-que Design in expanding the marketing of its products. The results of this study are an application with social media in marketing UKM products.

Keywords: social commerce; UKM; information technology.

\section{PENDAHULUAN}

Perkembangan zaman terus melaju pesat. Teknologi akses komunikasi semakin maju memudahkan masyarakat dalam bersosialisasi. Kemudahan-kemudahan tersebut ditawarkan melalui munculnya banyak media sosial yang dapat digunakan oleh semua orang untuk berinteraksi atau sekedar mencari hiburan melalui dunia maya.

Kemajuan teknologi komunikasi ternyata dimanfaatkan juga oleh usaha kecil menengah dalam mengembangkan usahanya. Melalui media sosial yang kini bak jamur, banyak UKM yang memanfaatkannya sebagai sarana jual beli dengan customer di seluruh dunia.

Social commerce adalah salah satu istilah yang sering digunakan orang untuk menggambarkan model toko online yang memanfaatkan media sosial untuk mempromosikan produk. Social Commerce ternyata bukanlah istilah baru. Menurut wikipedia, istilah ini digunakan pada tahun 2005 oleh yahoo. Istilah ini digunakan untuk menggambarkan dua produk mereka baru dirilis, yaitu shoposphere dan pick list. Kedua produk/tools ini bertujuan untuk membantu menciptakan hubungan antara produk dan pembeli dengan menyediakan saran dan mengembangkan deskripsi yang dibuat pengguna. Dalam hal ini Social Commerce didefinisikan sebagai hubungan antara produk dan komunitas pembeli yang berinteraksi dengan satu sama lain melalui konten.

Perkembangan social commerce tidak hanya meliputi facebook, twitter saja, instagram sekarang ini berkembang sangat cepat. Dalam perbincangan WSJ dengan VP Facebook untuk Asia Pasifik Dan Neary, terungkap bahwa platform media sosial ini terus menambah jumlah pengguna di kawasan ini, meskipun program Free Basics (yang dahulu bernama Internet.org) mendapatkan tentangan di sejumlah negara. Selain menginformasikan jumlah angka soal pengguna Facebook di Asia Pasifik, Neary juga secara spesifik 
memberikan apresiasi terhadap jumlah pengguna aktif Instagram di Indonesia yang menurut data MAU (Monthly Active Users) mencapai 22 juta [1].

UKM Uni-que merupakan salah satu UKM yang berkembang dalam bidang souvenir dan pernakpernik, seperti gelang, bros, kalung dan lain sebagainya. Dengan kemajuan teknologi sekarang ini, UKM Uni-que design akan memadukan penjualan online yang telah dikembangkan dengan social commerce melalui media sosial instagram. Hal ini dikarenakan pengguna media sosial semakin bertambah setiap tahunnya. Diharapkan dengan adanya social commerce ini penjualan dapat berkembang tidak hanya di lokal namun di dunia.

\section{TINJAUAN PUSTAKA}

Menurut Marsden [2], social commerce merupakan "A subset of electronic commerce that involves using social media, online media that supports social interaction and user contributions, to assist in the online buying and selling of products and services". Social commerce sendiri bukan hal baru, istilah social commerce diciptakan oleh Yahoo pada tahun 2005. Apa yang baru adalah ekspansi dan pengaruh utama akan media sosial selama beberapa tahun terakhir. Teknologi media sosial dan $e$-commerce telah membuka berbagai peluang baru untuk monetisasi media sosial dengan e-commerce. Banyak contoh terbaru dari social commerce yang telah menggunakan teknologi baru dari media sosial yang menghubungkan platform media sosial dengan platform e-commerce, baik dengan membangun toko e-commerce langsung ke platform media sosial atau dengan mengizinkan pengunjung situs $e$-commerce untuk mengoneksikan akun media sosial yang dimiliki. Layanan seperti Facebook terkoneksi memungkinkan pengunjung untuk masuk ke situs e-commerce dengan menggunakan akun Facebook yang dimiliki. Social commerce dapat memberikan tiga manfaat bisnis. Pertama, monetisasi media sosial yang dapat membantu pelaku $e$ commerce untuk mempromosikan produknya. Kedua, optimasi penjualan $e$-commerce, yaitu meningkatkan nilai order rata-rata bagi pelaku e-commerce karena promosi yang dilakukan di media sosial dapat menjangkau target pasar yang lebih luas. Ketiga, inovasi model bisnis, yaitu menciptakan arus pendapatan baru dengan kurasi dan mendapatkan value dari konten media sosial. Untuk pelanggan, social commerce dapat meningkatkan pengalaman siklus pembelian dengan menawarkan kepercayaan, utilitas dan kesenangan dalam tiga bidang utama yaitu penemuan produk, pemilihan produk dan rujukan produk. Ada enam dimensi atau toolsets yang berbeda untuk social commerce yaitu Social Shopping, Ratings \& Reviews, Recommendations \& Referrals, Forums \& Communities, Social Media Optimization, dan Social Ads and Apps [3].

Sebuah website s-commerce adalah tempat di mana orang dapat berkolaborasi secara online, mendapatkan nasihat dari orang-orang terpercaya, menemukan barang dan jasa, dan kemudian membelinya. $S$-commerce memiliki tiga atribut utama yaitu : teknologi sosial media , interaksi masyarakat(komunitas) dan kegiatan perdagangan [3]. S-commerce adalah evolusi dari e-commerce dengan menggunakan teknologi Web 2.0. Gambar 1 menunjukkan evolusi e-commerce dengan social commerce.
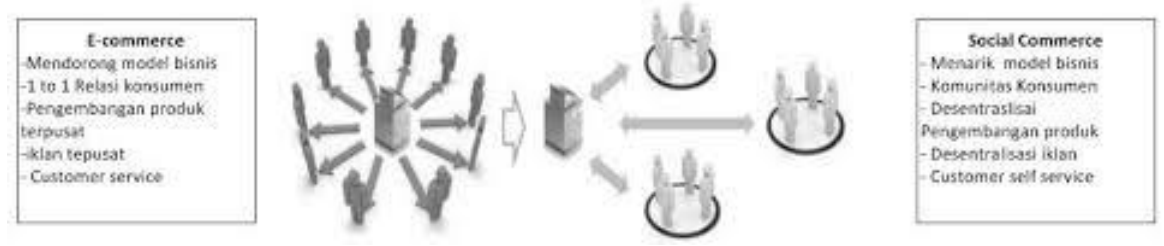

Gambar 1. Evolusi E-Commerce ke Social Commerce [4]

Social commerce juga telah di teliti oleh beberapa penelitian, berikut merupakan penelitian terkait dengan social commerce. Menurut penelitian muhammad ashur menjelaskan Pertumbuhan pesat media sosial di Indonesia membawa penggunanya ke tingkat di mana bentuk rencana bisnis yang baru dapat dikembangkan yaitu social commerce. S-commerce merupakan evolusi baru dalam dunia perdagangan internet yang memanfaatkan media sosial sebagai panggung bisnisnya. Penelitian ini bertujuan untuk menganalisis pengaruh dukungan sosial, persepsi risiko, dan interaksi sosial terhadap kepercayaan dan niat pembelian konsumen s-commerce di Indonesia. Responden berjumlah 148 pengguna facebook di Indonesia. Pengumpulan data melalui metode survei kuesioner elektronik yang telah disebar di jejaring sosial facebook. Metode dan teknik analisis data menggunakan Structural Equation Model (SEM) - Partial Least Square (PLS). Hasil penelitian menunjukkan bahwa variabel dukungan sosial memiliki pengaruh dominan terhadap niat pembelian konsumen. Temuan ini memberikan pemahaman baru tentang aktivitas konsumen di media sosial dan implikasinya pada strategi perusahaan s-commerce di Indonesia [5].

Penelitian kedua oleh Endang Supriyati mengatakan E-commerce berevolusi dengan mengadopsi web 2.0 yang mempunyai kemampuan meningkatkan partisipasi pelanggan dan meningkatkan nilai ekonomi. 
Fenomena baru ini dikenal dengan istilah social commerce (s-commerce). Kualitas website dipengaruhi tiga hal yaitu kualitas sistem (system quality), kualitas layanan (service quality) dan kualitas informasi (information quality). Kualitas pelayanan yang baik dapat membantu pengguna mendapatkan kekuatan penuh dari website dengan cara mencocokkan dengan harapan mereka. Kualitas informasi menunjukkan sejauh mana isi dari website tersebut tepat waktu (update), akurat, dan lengkap. Penelitian ini bersifat empiris dengan menerapkan model kualitas website pada dua s-commerce yaitu tokopedia.com dan lazada.co.id. Metode yang digunakan adalah analisa sistematis, perbandingan dan observasi. Dari model yang diterapkan didapat hasil bahwa tokopedia memiliki lebih banyak atribut-atribut kualitas website [6].

Penelitian terkait berikutnya membahas mengenai penjualan online. Banyaknya permintaan di bidang fashion menjadikan kota Semarang Jawa Tengah menjadi salah satu sentral produksi garment dengan berbagai model dan merk fashion yang ada. Dengan pertimbangan pemasaran yang tidak hanya di daerah setempat saja, banyak perusahaan garment di kota Semarang menerapkan penjualan online sebagai salah satu cara untuk memperluas jaringan pemasaran dari produk garment. Penelitian ini menghasilan sebuah sistem informasi penjualan berbasis web yang dirancang sebagai media promosi produk-produk garment, memperluas area penjualan, serta mempersingkat dan mempermudah transaksi [7].

Penelitian penjualan online juga terdapat pada prosiding dengan judul e-commerce goodybag. Goody bag spunbond merupakan salah satu karya dari UKM di Kudus. Dalam rangka memajukan usaha tersebut cara pemasaran ditingkatkan menggunakan web. Responsive web design (RWD) merupakan desain web yang memiliki tujuan untuk mengoptimalkan situs agar mudah dibaca dari berbagai perangkat, baik itu PC, smarphone maupun tablet.

Pengkodean jenis barang pada penjualan online ini menggunakan teknologi QR Code, dimana sebagai alat pembacanya menggunakan Barcode Scanner yang diterapkan di smartphone berbasis android. Hal ini digunakan untuk mempermudah pembeli dalam mencatat kode jenis barang yang akan dibeli. Karena menurut survey 500 orang, pengguna android di Indonesia mencapai 67,8 \%. Metode pengembangan system menggunakan waterfall yang meliputi analisa kebutuhan, desain system, penulisan kode program, pengujian program dan implementasi program. Dengan adanya e-commerce ini diharapkan penjualan dari vantacy shop dapat meningkat [8].

\section{METODE PENELITIAN}

Hasil kegiatan ini adalah diterapkannya website sebagai tempat penjualan yang terhubung dengan sosial media sebagai pendukung penjualan dari UKM. Penelitian ini dilakukan oleh dosen Fakultas Teknik Universitas Muria Kudus beserta mahasiswa dengan UKM Uni-Que Design untuk penerapan intelektual dosen dalam social commerce.

Social commerce merupakan sebuah alternatif wadah penjualan dengan memanfaatkan sosial media sebagai media promosi produk UKM. Selain itu sebuah website admin juga telah berhasil dibuat dalam kegiatan ini. Adapun tahapan metode penelitian yang terdiri dari analisa dan perancangan, pengembangan website, pengembangan s-commerce, pengembangan produk dan pelatihan.

\subsection{Analisa dan Perancangan}

Analisa dibutuhkan untuk memperoleh data-data yang digunakan dalam pembuatan social commerce ini. Data yang dibutuhkan meliputi data produk uni-que, narasi, biaya ongkos kirim, template untuk website.

Perancangan dalam penelitian ini menggunakan usecase diagram. Terdiri atas 2 aktor yaitu admin dan user. Di dalam perancangan terdapat beberapa alur yang diterapkan untuk menjadi proses dari sistem kerja social commerce.

\subsection{Pengembangan Website}

Dalam pengembangan website akan diterapkan menggunakan CMS (content management system) yaitu menggunakan wordpress. Di mana dalam website dilengkapi dengan link menuju ke media sosial seperti instagram, facebook, dan lain sebagainya. Isi dari website berisi produk-produk yang dijual oleh UKM Uni-que. Setiap produk memiliki penjelasan dan dilengkapi dengan harga dari masing-masing produk. Menu yang terdapat pada website berisi home, how to buy, catalogue, tarif ekspedisi. Pada menu how to buy menjelaskan bagaimana cara dan mekanisme berbelanja di uni-que design. Selain itu ada menu catalogue, di sini berisi produk-produk secara lengkap. Dalam belanja online yang harus diinformasikan yaitu tarif ekspedisi. Karena selain biaya dari produk yang akan dibeli, kita juga membebani pembeli untuk membayar ongkos kirim ke tujuan pembeli. Oleh karena itu kita lengkapi dengan informasi tarif ekspedisi dengan berbagai macam ekspedisi dan tarifnya. 


\subsection{Pengembangan Social Commerce}

Tren belanja online secara tidak langsung mengubah penjualan konvensional menjadi online. Hal ini didukung dengan banyaknya media social yang digunakan sebagai salah satu alternatif penjualan. Hal inilah yang menjadikan sosial media dan penjualan menjadi suatu social commerce. Dalam penelitian ini memanfaatkan media sosial sebagai cara untuk memperluas penjualan ke seluruh penjuru nasional dan mancanegara. Salah satu media sosial yang kita gunakan adalah instagram. Selain itu kita menggabungkan sosial media ke dalam website penjualan yang dibuat dalam penelitian ini.

\subsection{Pengembangan Produk Souvenir}

Tahapan pengembangan produk merupakan tahapan dalam membuat produk lebih bervariasi. Pada tahapan ini kita menghimpun data yang berisi variasi produk yang nantinya akan diproduksi oleh UKM uni-que design.

\subsection{Pelatihan}

Pada tahapan pelatihan ini bertujuan untuk pendampingan penggunaan social commerce kepada UKM dalam memasarkan produknya. Pelatihan ini diadakan pada bulan November 2017. Persiapan pada tahapan ini adalah membuat modul yang berisi penjelasan mengoptimalkan pemasaran dengan menggunakan social commerce.

\section{HASIL PENELITIAN}

Penelitian ini menghasilkan sebuah aplikasi yang dapat dipergunakan oleh UKM uni-que design dalam memperluas pemasaran produknya. Pada Gambar 2 merupakan salah satu media sosial yang dihasilkan pada penelitian ini. Di mana isi dari produk UKM ditampilkan di sana. Instagram dari UKM ini adalah uniquekudus dan informasi ini juga disampaikan melalui website.

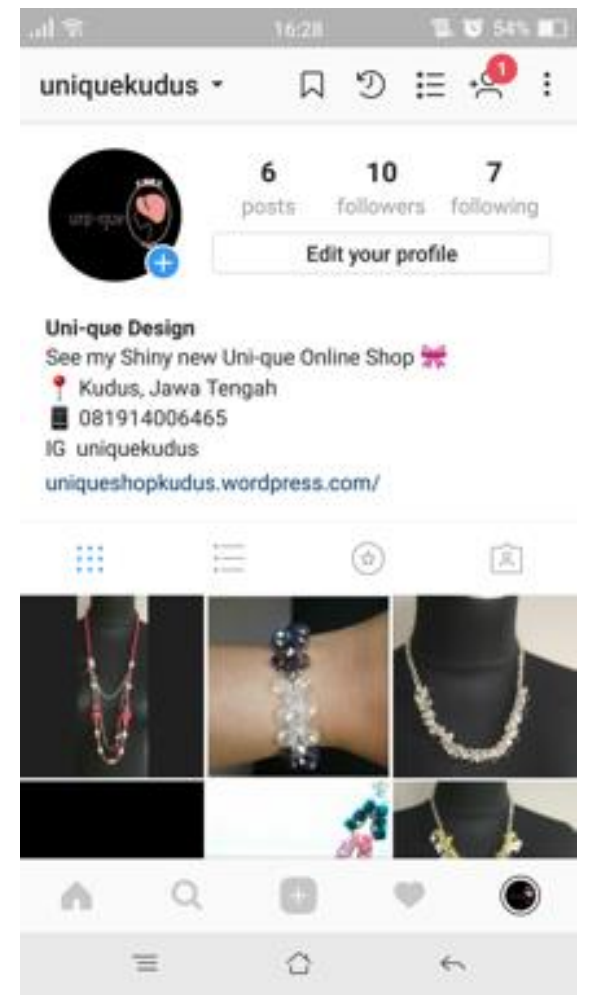

\section{Gambar 2. Produk Uni-que Design pada Sosial Media}

Website uni-que design dapat diakses melalui media sosial ataupun dari browser yang disediakan pada ponsel maupun laptop. Pada Gambar 3 menunjukkan salah satu produk dari uni-que design yang dipasarkan. 


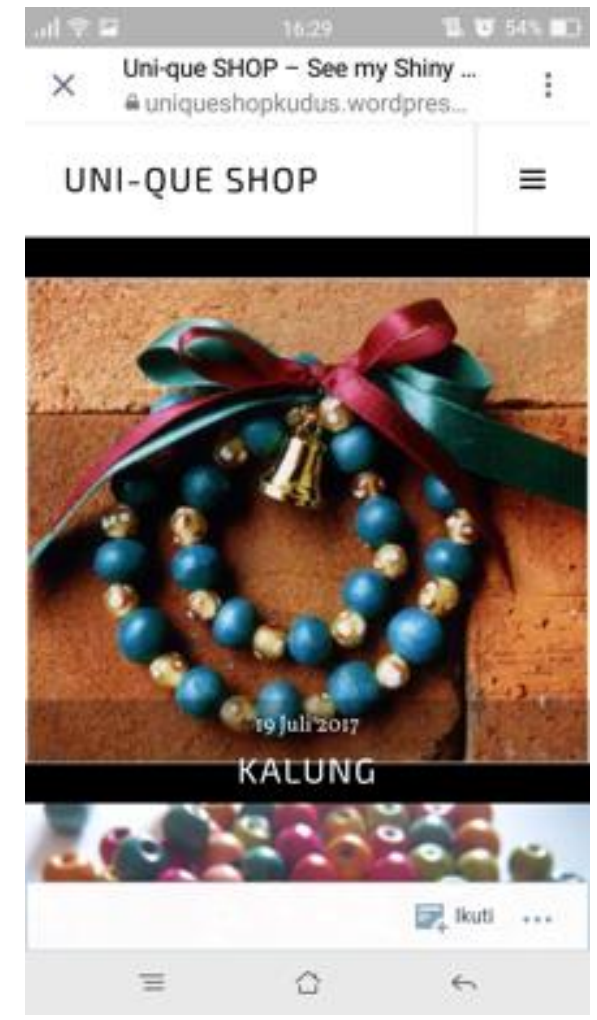

\section{Gambar 3. Website yang dapat Diakses Melalui Media Sosial}

Pada Gambar 4 merupakan menu yang disediakan oleh website uni-que design. Terdiri dari home, catalogue, how to buy. Serta informasi ekspedisi juga disediakan, salah satunya adalah sicepat dan jne. Dengan adanya link ekspedisi ini, pembeli dimudahkan untuk dapat melihat biaya ongkos kirim jika produknya dikirim. Hal ini terlihat pada Gambar 5.

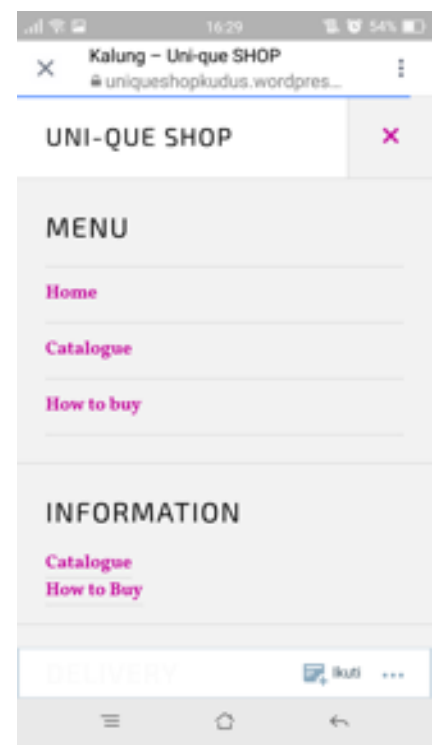

Gambar 4. Menu yang disediakan pada Website Uni-Que Design 


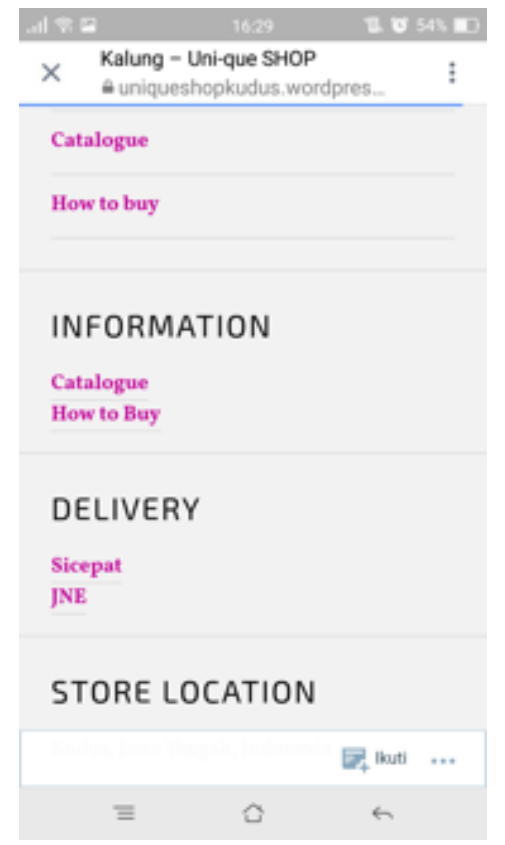

Gambar 5. Menu Pengiriman Barang Ekspedisi

\section{KESIMPULAN}

Berdasarkan permasalah yang dialami UKM Uni-que design, maka dapat diambil beberapa kesimpulan yaitu Menghasilkan sebuah website penjualan yang dilengkapi dengan media sosial instagram sebagai alternatif penjualannya. Yang kedua pemasaran produk UKM dapat menyebar lebih luas dengan pemanfaatan social commerce ini.

\section{UCAPAN TERIMA KASIH}

Terima kasih kami ucapkan kepada Universitas Muria Kudus, yang telah memfasilitasi kegiatan tri dharma ini. Atas bantuan materil dan non materil kegiatan ini dapat berjalan dengan baik serta memberikan manfaatn yang positif terhadap UKM uni-que design Kudus.

\section{DAFTAR PUSTAKA}

[1] A. Karimmudin, "Pengguna Aktif Instagram di Indonesia capai 22 Juta," Daily Social ID, 16-Mar-2016. .

[2] P. Marsden and S. Group, "Social commerce: Monetizing Social media," in Social commerce: Monetizing Social media, pp. 1-26.

[3] T.-P. Liang and E. Turban, "Introduction to the Special Issue Social Commerce: A Research Framework for Social Commerce," Int. J. Electron. Commer., vol. 16, no. 2, pp. 5-14, Dec. 2011.

[4] A. A. Rad and M. Benyoucef, "A Model for Understanding Social Commerce," J. Inf. Syst. Appl. Res. JISAR, vol. 4, no. 2, pp. 63-72, Agustus 2011.

[5] M. Ashur, "Pengaruh Dukungan Sosial, Persepsi Risiko dan Interaksi Sosial terhadap Kepercayaan dan Niat Pembelian Konsumen pada Media S-Commerce (Studi Pada Konsumen S-Commerce Di Indonesia)," J. Bisnis Dan Manaj., vol. 3, no. 1, pp. 109-119, 2016.

[6] E. Supriyati, "Studi Empirik Social Commerce (S-Commerce) dari Sudur Pandang Kualitas Website," Simetris J. Tek. Mesin Elektro Dan Ilmu Komput., vol. 6, no. 1, p. 89, Apr. 2015.

[7] T. Listyorini, "Analisis Sistem Penjualan Online pada Perusahaan Garment di Semarang," Simetris J. Tek. Mesin Elektro Dan Ilmu Komput., vol. 1, no. 1, p. 39, Jun. 2013.

[8] T. Listyorini, "E-Commerce Goody Bag Spunbond menggunakan WR Code Berbasis Web Responsif pada Toko Vantacy Shop," in SEMNASTEKNOMEDIA, 2014. 